$\mathcal{G}_{\text {https://doi.org/10.3765/sp.10.2n }}^{\text {Semantics \& Pragmatics Volume 10, Article 2n: 1-4, } 2017}$

\title{
A note on temporal reference, anaphora, and Kamp's motivations for DRT
}

\author{
Barbara H. Partee \\ University of Massachusetts, Amherst
}

Invited commentary

Keywords: tense, reference, anaphora, DRT

The publication of the English original of Hans Kamp's "Events, discourse representations, and temporal reference", previously published only in French translation (Kamp 1981b), is a welcome addition to the literature. Not only does it make that paper much more widely accessible than it has been previously, which is valuable in itself for the many good and still-timely ideas it contains, but the paper and the new postscript included with it do indeed offer an important clarification of the motivations for the development of Discourse Representation Theory. This paper is, to me, an example of Kamp at his best, beautifully structured and full of subtle observations of both linguistic and philosophical interest. That's the biggest reason that it's nice to see it published now. This note about its relation to the motivations for DRT is just a supplement to the postscript, with the same goal of clarifying the historical record.

The postscript gives a good explanation of the historical context of the paper and the reason for publishing it now. And what Kamp says there about my role in leading people to a mistaken idea of the motivations for the main ideas of DRT seems completely plausible to me. According to Kamp, my paper (Partee 1984) was apparently responsible for the idea that DRT was principally developed as a theory of nominal anaphora, including discourse anaphora and donkey sentences. And indeed that was how I thought of it.

At the time that I was working on Partee 1984, I knew Kamp's earliest work on events, temporal interpretation and the two past tenses in French, Kamp 1979 and Kamp \& Rohrer 1983. And of course I knew his classic DRT paper, Kamp 1981a, which was presented at an Amsterdam Colloquium in 1980 and first published in the proceedings in 1981. But those two lines of work

(C)2017 Barbara H. Partee

This is an open-access article distributed under the terms of a Creative Commons Attribution License (https://creativecommons.org/licenses/by/3.0/). 
were not connected in my own mind. I viewed Hans's DRT paper in the light of Irene Heim's dissertation (Heim 1982), and thought that the emphasis in Hans's work, as in Irene's, was on separating indefinites from quantificational expressions and treating indefinites as not having any quantificational force of their own; formalizing the notion of "discourse referents" from Karttunen 1969 and using it to make sense of the notion of "indefinite reference"; and on seeing the connection between donkey sentences and discourse anaphora. I didn't in my own mind connect any of that with Hans's work on temporal reference.

In my 1984 paper I was building directly on Hinrichs's MA thesis (Hinrichs 1981). (It was written in German, and my German is weak, but it concerned the past and past perfect tenses in English, so the examples were all English sentences, and it was written within the framework of DRT, so I was able to read it.) Hinrichs's thesis did concern temporal anaphora in part; but that notion was not entirely new then, being found at least implicitly in Reichenbach's work (Reichenbach 1947) and explicitly in my earlier work (Partee 1973), but it did not exploit the full power of DRT to handle a wider variety of kinds of anaphora. The motivation for my 1984 paper was to show how DRT could help provide a more principled basis for modeling the similarities between nominal and temporal anaphora that I had uncovered in my 1973 paper. So I intended to be helping by showing that what Kamp and then Hinrichs had done about temporal interpretation and reference time could be extended to the broader range of temporal anaphora, including bound anaphora and donkey anaphora in the temporal domain.

So in short, I cannot argue at all with what Hans says about my work in his postscript: I indeed had no idea that the original motivation for DRT came from the temporal domain. And what I can also see from the postscript is that the aspects of DRT most central for Kamp are not the aspects of it that were most central to me. I had a diffident and even skeptical attitude toward the idea that some representational level mediating between syntax and model-theoretic semantics is really necessary. Chierchia and Rooth had shown that the notion of "accessibility to anaphora" of Heim's File Change Semantics (Heim 1982, Ch.3 and Heim 1983) and Kamp's DRT could be reformalized without using an intermediate representational level (Chierchia \& Rooth 1984), and Zeevat also did a reworking of DRT in which Kamp's "discourse referents" are simply variables together with certain restrictions a fully compositional analysis (Zeevat 1989). For me what was most valuable in Kamp's and Heim's work was the treatment of indefinites (and in Heim's 
work, the account of the contrast between indefinites and definites), of quantification, and of anaphora. And I hadn't seen any of that in Kamp's work on temporal reference - and that also does not figure in this paper of his, which I had read long ago in its French version - , and that's what I was trying to add.

\section{References}

Chierchia, Gennaro \& Mats Rooth. 1984. Configurational notions in Discourse Representation Theory. North East Linguistic Society (NELS) 14.

Heim, Irene. 1982. The semantics of definite and indefinite noun phrases. 2011 edition. University of Massachusetts at Amherst dissertation. http: //semanticsarchive.net/Archive/jA2YTJmN.

Heim, Irene. 1983. File Change Semantics and the Familiarity Theory of definiteness. In Rainer Bäuerle, Christoph Schwarze \& Arnim von Stechow (eds.), Meaning, use, and interpretation of language (Grundlagen der Kommunikation und Kognition), 164-190. de Gruyter.

Hinrichs, Erhard W. 1981. Temporale Anaphora im Englischen. EberhardKarls-Universität Tübingen Staatsexamen thesis.

Kamp, Hans. 1979. Events, instants and temporal reference. In Rainer Bäuerle, Urs Egli \& Arnim von Stechow (eds.), Semantics from different points of view (Springer Series in Language and Communication 6), 376-417. Berlin: Springer. https://doi.org/10.1007/978-3-642-67458-7_24.

Kamp, Hans. 1981a. A theory of truth and semantic representation. In Jeroen A. G. Groenendijk, Theo M. V. Janssen \& Martin J. B. Stokhof (eds.), Formal methods in the study of language: part 1 (Mathematical Centre Tract 135), 277-322. Amsterdam: Mathematisch Centrum.

Kamp, Hans. 1981b. Evénements, représentations discursives et référence temporelle. Langages 15(64). 39-64. https://doi.org/10.3406/lgge.1981. 1884 .

Kamp, Hans \& Christian Rohrer. 1983. Tense in texts. In Rainer Bäuerle, Christoph Schwarze \& Arnim von Stechow (eds.), Meaning, use, and interpretation of language (Grundlagen der Kommunikation und Kognition), 250-269. de Gruyter.

Karttunen, Lauri. 1969. Discourse referents. In International Conference on Computational Linguistics (COLING) 1969: Preprint no. 7o. http://web. stanford.edu/ laurik/publications/archive/discref.pdf. 
Partee, Barbara Hall. 1973. Some structural analogies between tenses and pronouns in English. The Journal of Philosophy 70(18). 601-609. https: //doi.org/10.2307/2025024.

Partee, Barbara Hall. 1984. Nominal and temporal anaphora. Linguistics and Philosophy 7(3). 243-286. https://doi.org/10.1007/BFoo627707.

Reichenbach, Hans. 1947. Elements of symbolic logic. New York: MacMillan.

Zeevat, Henk. 1989. A compositional approach to Discourse Representation Theory. Linguistics and Philosophy 12(1). 95-131. https://doi.org/10.1007/ bfoo627399.

Barbara H. Partee

Department of Linguistics N408 Integrative Learning Center 650 North Pleasant Street University of Massachusetts at Amherst Amherst, MA 01003-1100 USA

partee@linguist.umass.edu 